\title{
EARTHQUAKE-INDUCED ROCKFALLS IN SANTOMERI VILLAGE, WESTERN GREECE
}

\author{
Lainas S. ${ }^{1}$, Koulouris S. ${ }^{1}$, Vagenas $\mathrm{S.}^{1}$, Depountis $\mathrm{N}^{2}$, \\ Sabatakakis N. ${ }^{1}$ and Koukis G. ${ }^{1}$ \\ ${ }^{1}$ University of Patras, Department of Geology, Laboratory of Engineering Geology, 26500 Patras, Greece, \\ splainas@upatras.gr \\ ${ }^{2}$ Region of Western Greece,Directorate of Public Works,nikosdepountis@hotmail.com
}

\begin{abstract}
On the 8th of June 2008 an earthquake of magnitude Ms=6.5 occurred in Western Greece, affecting Achaia and Ilia Prefectures. According to state reports 2 casualties occurred, 214 people were injured and more than 15 villages and towns suffered extensive damages in properties and infrastructures. Among the secondary phenomena that were reported were extensive rockfalls that affected Santomeri village; a small village located on the western slope of the Scolis mountain. Large-sized limestone boulders, some reaching a volume up to $10 \mathrm{~m}^{3}$ stroke houses and blocked roads, fortunately without casualties. The village was temporarily evacueated and the Laboratory of Engineering Geology was commissioned to undertake an Engineering Geological appraisal in order to investigate the extent of the rockfall events, assess the rockfall hazard and propose retention and protective measures so the area to be soon re-inhabited. After conducting a detailed engineering geological and geotechnical survey which included large scale engineering geological mapping, rockmass characterization and laboratory tests the inhabited area was initially divided in two zones of different rock fall risk level. By performing rockfall analyses in critical traverses a rock fall retention system, $325 \mathrm{~m}$ long in total, comprising rock fall barrier was finally proposed.
\end{abstract}

Key words: Earthquake-induced rock fall, rock fall analysis, Achaia, Western Greece

\section{Introduction}

On the $8^{\text {th }}$ of June 2008, 15:25 local time, a strong earthquake of magnitude Ms=6.5 stroke Western Greece, affecting mainly Achaia and Ilia Prefectures. According to state reports two people were killed, 214 were injured and more than 15 villages and towns suffered extensive damages in properties and infrastructures. Among the earthquake's secondary phenomena, apart from surface ruptures, some liquefaction phenomena, slope failures etc there were large scale rock falls. In particular, extensive rock falls manifested at "Skolis" mountain. Some roads were blocked by the rockfalls, houses were destroyed, fortunately without casualties. As a result, three villages were temporarily evacuated ("Haraygi", "Portes" and "Santomeri") as a measure to protect inhabitants from probable reactivation during an after-shock. After field reconnaissance from the Department of Geology it was decided that only Santomeri village faces serious rockfall risk and so the Department of Geology was commissioned to undertake an engineering geological appraisal in order to assess rockfall hazard and to propose retention-protective measures so the area to be soon re-inhabited. 


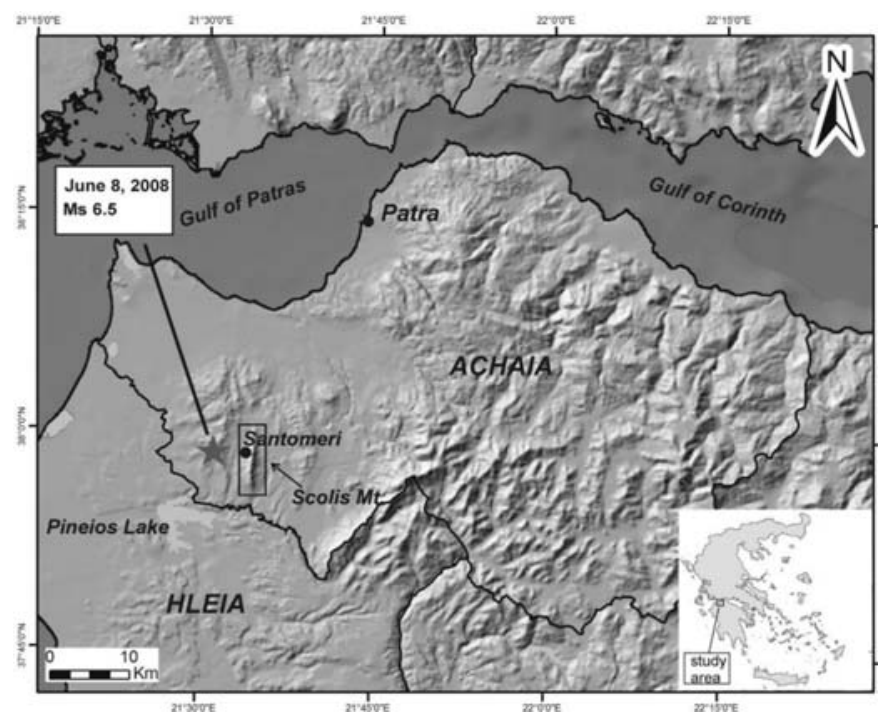

Fig. 1: Simplified map showing the location of the study area and the epicentre of the $8^{\text {th }}$ of June 2008 earthquake.

This paper focuses on estimating the critical rockfall parameters such as kinetic energy, bouncing height, rock endpoints and coefficients of restitution, in order to propose the appropriate design specifications of the required retention measures.

\section{Geological setting}

Santomeri village is founded on the western slope of "Skolis" mountain (Fig. 1) at an elevation of 400$500 \mathrm{~m}$. This mountain is a long morphological feature with $\mathrm{N}-\mathrm{S}$ orientation with maximum elevation of about $970 \mathrm{~m}$. It is characterized by steep slopes, especially at its western part. Steepness is closely related to the geological and tectonic features. At higher elevations Cretaceous and Eocenic limestones of Gabrovo-Tripolis Geotectonic Zone (Dercourt, 1964, Fleury, 1980) form slopes inclined up to 90 degrees and up to 80 meters high, while the eastern and western slopes which are composed by Flysch of the same Zone and scree, form gentler slopes that incline at about 45-50 degrees.

The main tectonic feature of this area is the overthrusting of Cretaceous limestones on the Flysch (Fleury, 1980). This has caused intense deformation and fracturing of the rockmass making it more susceptible to slope instability phenomena.

\section{Methods}

\subsection{General}

The research included engineering geological mapping at a 1:1000 scale, rockmass characterization and classification, recording and classification of fallen rocks according to their estimated volume and finally rock fall statistical analyses in seven (7) selected traverses. Along each traverse rockfall statistical analyses were done, in order to compute kinetic energy, bounce height and maximum travel distance. The coefficients of normal and tangential restitution were estimated from back calculation of known rock paths and rock endpoints according to field observations of the rockfall events. 


\subsection{Engineering geological conditions}

In order to investigate the engineering geological conditions and the factors that control slope stability, engineering geological mapping at 1:1000 scale was conducted. Due to the absence of recent topographic data mapping was based on the existing maps of 1:5000 scale and on satellite images. These maps were georeferenced to the Greek Geodetic Referencing System (GGRS 87) and digitized. The map's data, concerning newly constructed houses and road network was updated after field work.

Three engineering geological units were mapped, as shown in the corresponding engineering geological map (Fig. 2). From the most recent to the older these are:

\section{Recent rockfall debris}

They are loose deposits of rockfall debris consisted of grey and white limestone blocks of various size. They were deposited on the slope's surface after weathering of the limestones and during previous earthquakes. The area that they cover was extended during the 2008 earthquake.

Scree

They are loose to semi-cemented Quaternary deposits which consist of white and gray limestone fragments of various size mixed with brown sandy or clayey matrix derived from the weathering of limestone and flysch basement rocks.

Flysch

It has Oligocenic age and belongs to the Gavrovo-Tripoli Geotectonic Zone. It consists of successive medium-bedded fine-grained sandstones and mudstones of brown or gray colour. They are susceptible to weathering processes and, as a result, they are characterized by up to 1-meter thick weathering mantle. Besides, along the thrust zone with the limestones, flysch is intensely deformed, fractured and folded.

Limestones

Grey and white gray limestones interbedded with marly limestones of Cretaceous and Eocene age that belong to the Gavrovo-Tripolitsa Geotectonic Zone. They are formations of high strength with continuous bedding, inclined opposite to the slope.

The engineering geological map also depicts the main rockfall path that destroyed a house and the traces of the seven rockfall analysis traverses.

\subsection{Rock fall recording}

In order to estimate the most "possible" rock fall traces fallen rock boulders were recorded, mainly inside and near the inhabited area, even if scarce rock boulders of various size were also found in the broader area as a result of older rock fall events. Recording was done by locating each boulder by GPS and classifying each one according to its source material, origin, and estimated volume. Recording focused on boulders of estimated volume more than $2 \mathrm{~m}^{3}$ which were divided into four (4) volume classes. As shown in Fig 3, the most recordings belong to the volume classes between 2 and $5 \mathrm{~m}^{3}$. It must be noted that many of the recorded volumes may not represent the original volumes of the detached blocks, because many of them could have been broken during falling and crashing on the slope.

\subsection{Rockmass classification - slope stability conditions}

In order to estimate rockmass quality and assess slope stability conditions geomechanical descrip- 


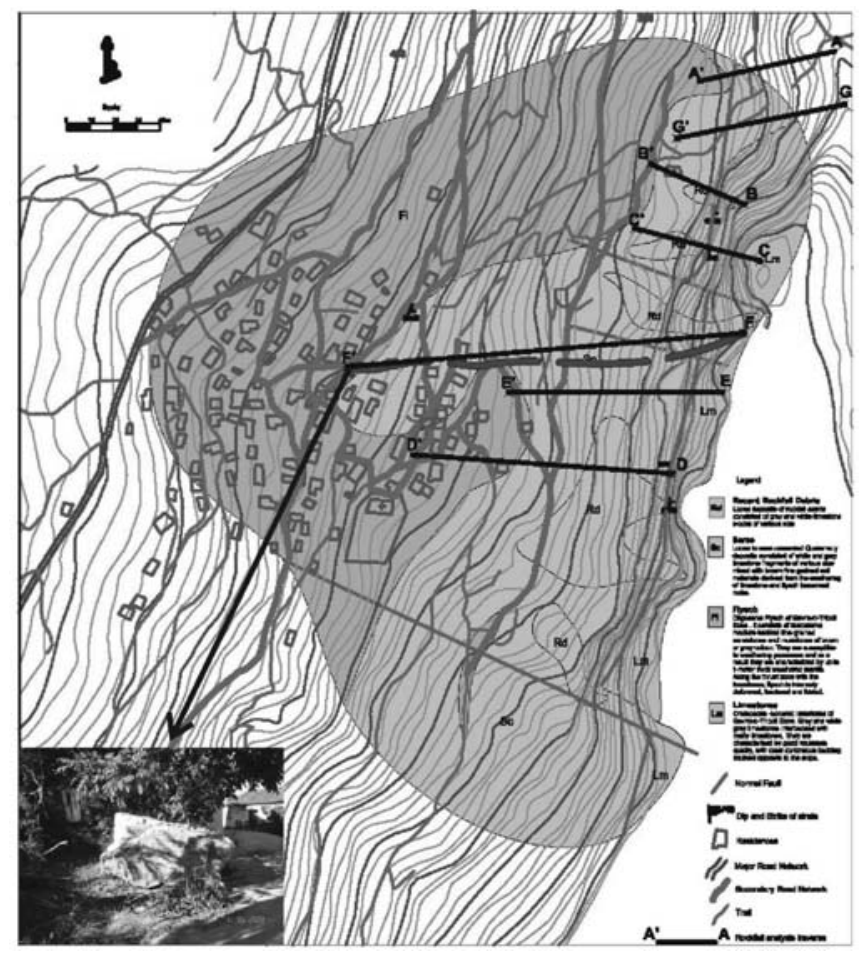

Fig. 2: Engineering Geological map of Santomeri area also showing the seven rock fall traverses and the courseendpoint of a large limestone boulder.

Table 1.

\begin{tabular}{|c|c|c|c|c|c|c|c|c|}
\hline $\begin{array}{c}\text { Disc. } \\
\text { Type/Set }\end{array}$ & $\begin{array}{c}\text { Orienta- } \\
\text { tion }\end{array}$ & Aperture & Spacing & Persistence & Roughness & JRC & JCS (MPa) & $\begin{array}{c}\text { Filling } \\
\text { Material }\end{array}$ \\
\hline $\begin{array}{c}\text { Bedding } \\
\text { Plane/B }\end{array}$ & $89 / 16$ & $2,5-10 \mathrm{~mm}$ & $\begin{array}{c}200-600 \\
\mathrm{~mm}\end{array}$ & $10-20 \mathrm{~m}$ & $\begin{array}{c}\text { Rough } \\
\text { undulating }\end{array}$ & $10-12$ & $130 \pm 50$ & $\begin{array}{c}\text { Clean - } \\
\text { Sandy }\end{array}$ \\
\hline Fault/F & $265 / 85$ & $10-100 \mathrm{~cm}$ & $\begin{array}{c}600-2000 \\
\mathrm{~mm}\end{array}$ & $>20 \mathrm{~m}$ & $\begin{array}{c}\text { Smooth } \\
\text { undulating }\end{array}$ & $8-10$ & $110 \pm 40$ & $\begin{array}{c}\text { Clean - } \\
\text { Sandy }\end{array}$ \\
\hline Joint/J1 & $266 / 54$ & $10-100 \mathrm{~cm}$ & $\begin{array}{c}600-2000 \\
\mathrm{~mm}\end{array}$ & $>20 \mathrm{~m}$ & $\begin{array}{c}\text { Smooth } \\
\text { undulating }\end{array}$ & $8-10$ & $125 \pm 50$ & $\begin{array}{c}\text { Clean - } \\
\text { Sandy }\end{array}$ \\
\hline Joint/J2 & $182 / 82$ & $1-10 \mathrm{~cm}$ & $\begin{array}{c}200-600 \\
\mathrm{~mm}\end{array}$ & $10-20 \mathrm{~m}$ & $\begin{array}{c}\text { Smooth } \\
\text { undulating }\end{array}$ & $8-10$ & $115 \pm 45$ & $\begin{array}{c}\text { Clean - } \\
\text { Sandy }\end{array}$ \\
\hline
\end{tabular}

tion of discontinuities according to ISRM (1981) was performed. The joint-wall compression strength was estimated in the field by using Schmidt Hammer Test, while the limestone uniaxial compression strength and shear strength parameters were measured with laboratory tests in rock samples. It was found that rockmass is jointed by four (4) main discontinuity sets with mean dip/dip directions as shown in Table 1.

Rockmass quality was estimated according to GSI (Hoek and Marinos, 2000) and RMR (Beniawski, 1989) classification systems. Based on the discontinuities' properties and the bedding orientation RMR was estimated in the range of 55-65, classifying limestones as rockmass of "Good" to 

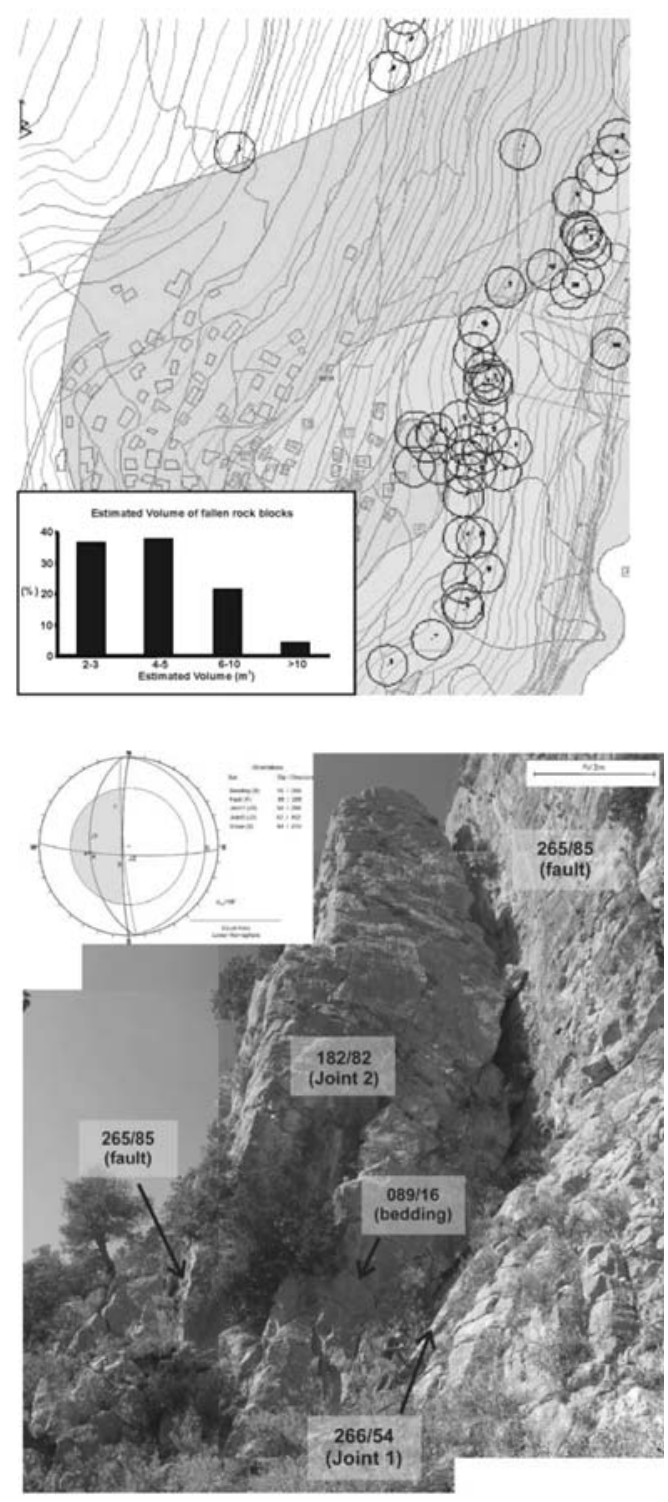

Fig. 3: Distribution of rock blocks around Santomeri village and corresponding graph, showing their estimated volume range.

Fig. 4: Major discontinuity sets and corresponding Major Planes Plot in Limestone.

"Medium" quality. GSI was estimated in the field in the range of 50-60.

Slope stability conditions were estimated by performing preliminary kinematic analysis after plotting the discontinuity sets in Schmidt's stereographs. As shown in the following Major Planes Plot (Fig. 4) instability can potentially occur in the following cases

a. Planar slide along set $\mathrm{J}_{1}$.

b. Wedge failure along the wedge formed by sets $\mathrm{J}_{1}$ and $\mathrm{J}_{2}$ (wedge $\mathrm{A}$ ).

It was finally concluded that stability is mainly governed by Joint set " $\mathrm{J}_{1}$ " which is oriented almost 
Table 2.

\begin{tabular}{|c|c|c|c|}
\hline Traverse & Length $(\boldsymbol{m})$ & Slope height $(\boldsymbol{m})$ & Average slope gradient (deg) \\
\hline A-A' & 120 & 60 & 26.6 \\
\hline B-B' & 80 & 65 & 38.7 \\
\hline C-C' & 100 & 90 & 43.5 \\
\hline D-D' & 210 & 110 & 27.5 \\
\hline E-E' & 150 & 110 & 36.1 \\
\hline F-F' & 340 & 190 & 29.2 \\
\hline G-G' & 120 & 50 & 22.8 \\
\hline
\end{tabular}

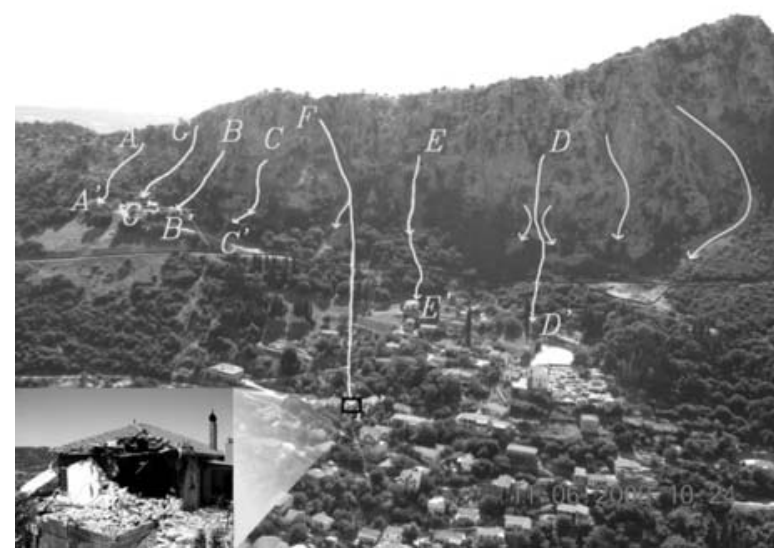

Fig. 5: Locations of the analysed Rockfall traverses. The location of a house destroyed by the rockfall is also shown.

parallel to the slope, by major fault surface (Fault "F") which has very high persistence and by Joint set " $\mathrm{J}_{2}$ " which is oriented perpendicularly to $\mathrm{J}_{1}$ and forms with it potentially unstable wedges.

Rock fall statistical analyses were performed in seven (7) traverses. The selection of the traverses was based on field observations concerning the traces of the major rockfall events and on the fallen rock recordings. Table 2 gives information about traverse length, average slope gradient and slope height. The location of each traverse correlated with the observed rockfall rock fall courses are also shown in Fig.5.

Rock fall analyses were performed by using Rocfall 4.0 (Rocscience Inc.). By using this software it was possible to determine Kinetic Energy, Velocity, "Bounce Height" and location of Rock Endpoints for the entire slope along each traverse. It also assisted to determine the most effective retaining measures to protect the village from possible future rock fall events. By performing these rock fall analyses coefficients or restitution $\left(\mathrm{R}_{\mathrm{N}}\right.$ and $\left.\mathrm{R}_{\mathrm{T}}\right)$ were also estimated for the specific site conditions.

For the design of each slope elevation data from the available maps was used with some modifications, if necessary. Because rockfall is strongly influenced by slope material (vegetation, soil cover etc), different slope surface materials were assigned in every traverse, according to field observations about vegetation type, scree cover, areas with clean bedrock etc.

Each rock fall analysis included 2000 throws of a single rock. Initiation points (data seeders) were assigned in each analysis, according to field observations and estimations regarding the most pos- 
Table 3.

\begin{tabular}{|c|c|c|}
\hline Slope material & $\boldsymbol{R}_{N}$ (mean values) & $\boldsymbol{R}_{T}$ (mean values) \\
\hline Limestone Bedrock & 0.550 & 0.920 \\
\hline Soil with little vegetation & 0.290 & 0.550 \\
\hline Soil with tree vegetation & 0.300 & 0.800 \\
\hline Talus cover & 0.320 & 0.820 \\
\hline Talus with vegetation & 0.320 & 0.800 \\
\hline Asphalt & 0.400 & 0.900 \\
\hline
\end{tabular}

sible sites for rock falling. Each slope was further divided in different segments in order to assign different slope materials. In every analysis rockfall parameters were calculated in 100 points along each slope making possible to graphically view calculations along the slope.

Because $R_{N}$ and $R_{T}$ coefficients can not be directly measured, they were estimated by performing back analysis calculations. Every analysis started by putting as input values suggested values of $R_{N}$ and $\mathrm{R}_{\mathrm{T}}$ for every material, according to the literature. As a second step, each analysis was calibrated in order to match the results with known rock paths and endpoints according to field observations, estimating, finally, $\mathrm{R}_{\mathrm{N}}$ and $\mathrm{R}_{\mathrm{T}}$ coefficients for the specific site conditions. For slope friction angle default values were used, while slope roughness values were based on the topographical accuracy with a standard deviation of 2 degrees.

Data collectors were finally put in selected points along the slope in order to get information about the necessary absorption capacity of the required retaining measures.

\section{Conclusions - Results}

Rock fall analyses mainly aimed to assess rockfall hazard in Santomeri village and to propose retention-protective measures so the area to be soon re-inhabited after the earthquake. Besides, with this research it was possible to estimate critical rockfall parameters such as Kinetic Energy, Bouncing Height, Rock Endpoints and Coefficients of Restitution.

Coefficients of normal and tangential Restitution were estimated for every material that covers the slope surface along the traverses. Proposed values for similar conditions were initially used and then the model was calibrated so that the results match to field observations regarding fall traces and rock endpoints. The mean values of the finally estimated coefficients are shown in Table 3.

After performing the analyses in all traverses it was possible to estimate the distribution of every computed parameter (Table 4). Computed results were collected by assigning in each analysis "data collector" points located at sites where the construction of retentions measures had been initially proposed. It was found that Kinetic Energy varies between 3000 and $8000 \mathrm{~kJ}$ with the lower values at north and the higher at south. Travel velocity and Energy were mostly affected by slope steepness and slope surface material, especially in areas of clean limestone bedrock or by the presence of tall trees. Very steep segments along the slopes favour free falling instead of bouncing or rolling, while the crushing of rocks on tall trees results to sudden modifications of Kinetic Energy and rockfall course. 


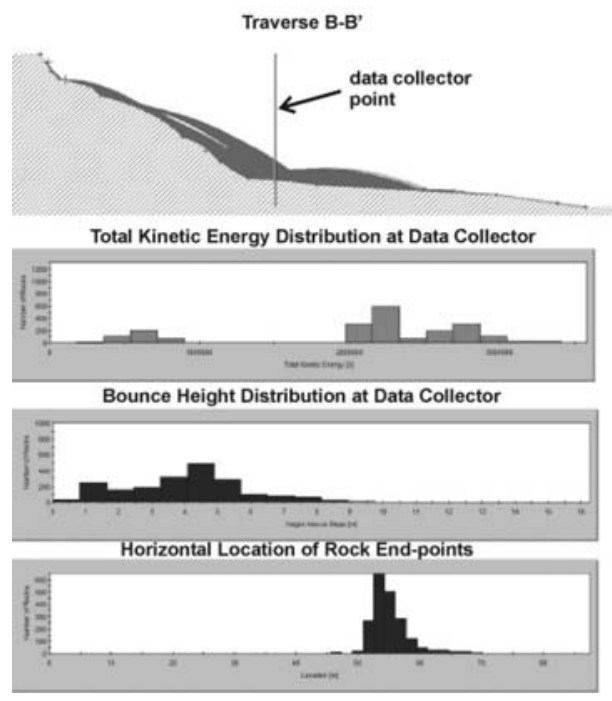

Fig. 6: Rock fall analysis results along traverse B-B'.

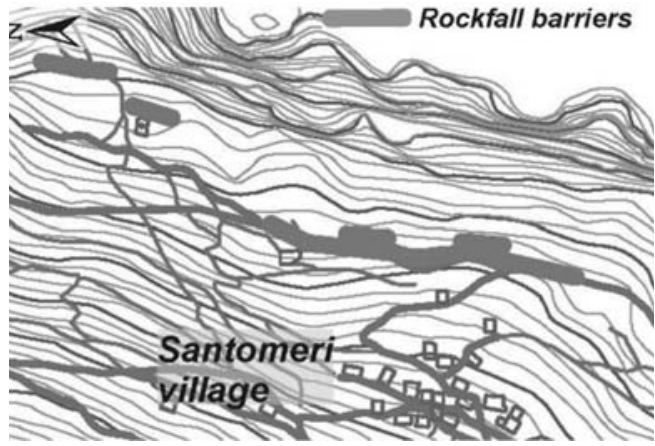

Fig. 7: Plan of the proposed Rockfall protection barriers.

Table 4.

\begin{tabular}{|c|c|c|c|c|c|}
\hline Traverse & $\begin{array}{l}\text { mass } \\
(\text { kgr })\end{array}$ & $\begin{array}{c}\text { Estimated } \\
\text { Volume }\left(\mathrm{m}^{3}\right)\end{array}$ & $\begin{array}{c}\text { Total Kinetic Energy } \\
(k J)\end{array}$ & $\begin{array}{l}\text { Bounce height } \\
\text { (m) }\end{array}$ & $\begin{array}{c}\text { Maximum } \\
\text { endpoints }(m)\end{array}$ \\
\hline A-A' & 5200 & 2 & $\begin{array}{c}\leq 350 \text { (90\% of throws) } \\
\text { Maximum: } 390\end{array}$ & $\begin{array}{l}\leq 0.8 \text { ( } 80 \% \text { of throws }) \\
\text { Maximum: } 3\end{array}$ & 120 \\
\hline B-B' & 7000 & 3 & $\begin{array}{c}\leq 3000 \text { (95\% of throws) } \\
\text { Maximum: } 3350\end{array}$ & $\begin{array}{l}\leq 4 \text { (80\% of throws) } \\
\text { Maximum: } 5\end{array}$ & $50-60$ \\
\hline C-C' & 65000 & 25 & $\begin{array}{c}\leq 13000 \text { ( } 85 \% \text { of throws }) \\
\text { Maximum: } 16500\end{array}$ & $\leq 1.5$ & $80-90$ \\
\hline D-D' & 5000 & 3 & $\begin{array}{c}\leq 4000(80 \% \text { of throws }) \\
\text { Maximum: } 7500\end{array}$ & $\leq 0.6$ & $70-90$ \\
\hline E-E' & 5000 & 2.5 & $\begin{array}{c}\leq 2300 \text { (80\% of throws) } \\
\text { Maximum: } 2800\end{array}$ & $\begin{array}{c}\leq 3 \text { (90\% of throws) } \\
\text { Maximum: } 5\end{array}$ & 190 \\
\hline F-F' & 16000 & $6-7$ & $\begin{array}{c}\leq 8000 \text { (95\% of throws) } \\
\text { Maximum: } 10000\end{array}$ & $\leq 2$ & 300 \\
\hline G-G' & 10000 & $3.5-4$ & $\begin{array}{c}\leq 2500 \text { (90\% of throws) } \\
\text { Maximum: } 3200\end{array}$ & $\leq 1.5$ & 130 \\
\hline
\end{tabular}

Bounce heights were generally found up to 4 meters. They were strongly influenced by the slope surface materials and by intense changes in topography. Higher Bounce heights were calculated in sites of exposed limestone bedrock.

Rock endpoints are generally between 100-300 meters from the start point of each traverse. The final endpoint was strongly influenced by topography and steep modifications of slope gradient. Sudden changes from steep to gentle slope segments and energy reduction due to crushing force sometimes 
rocks to stop moving and rest on the slope, before reaching the maximum possible endpoint. The village is within the above endpoint range since it is located within a distance less than $250 \mathrm{~m}$ from rockfall affected zones. Fig. 6 shows an example of the analysis results, as calculated along traverse B-B'.

Rockfall protection barriers with absorption capacity of $3000 \mathrm{~kJ}, 5$ meters high and having a total length of 325 meters were initially proposed in selected places along the slope, as shown in Fig. 7.

\section{Acknowledgments}

The work was carried out under the support of the Region of Western Greece. The authors wish to express their sincere appreciation to its generous support.

\section{References}

Bieniawski, Z.T., 1989. "Engineering rock mass classifications." Published by John Wiley \& Sons, New York, $251 \mathrm{pp}$.

Decourt, J., 1964. Contribution à l' étude géologique d'un secteur du Péloponnèse septentrional. Ann géol. Pays. Hellen., 15, pp. 1-418, Athènes.

Fleury. J.J., 1980. Les zones de Gavrovo-Tripolitza et du Pinde-Olonos (Grèce continetale et Peloponnèse du Nord). Evolution d'une plateforme et d'un bassin dans leur cadre alpin. Soc. Géol. Nord. Publ. no 4, 651 pp., Lille.

I.S.R.M. Suggested Methods,1981. «Rock Characterization Testing and Monitoring», Editor E. Brown, Pergamon Press.

Hoek, E. and Brown, E.T., 1997. "Practical estimates of rock mass strength". Intnl. J. Rock Mech.\& Mining Sci.\& Geomechanics Abstracts. 34(8), pp. 1165-1186

HoeK, E., Brown, P. and Bennisi, M., 1998. "Applicability of the Geological Strength Index (GSI) classification for very weak and sheared rock masses. The case of the Athens Schist Formation". Bull. Engg. Env. 57(2), pp. $151-160$.

HoeK, E. and Marinos, P., 2000. Predicting Tunnel Squeezing. Tunnels and Tunneling International, Part 1 - November Issue 2000, pp. 45 - 51, Part 2 - December 2000,pp. 34 - 36.

ITSAK, 2008. The Achaia-Hleia earthquake. $4^{\text {th }}$ Technical Report, Institute of Engineering Seismology and Antiseismic Constructions, 67pp, Thessaloniki. Available online at: http://www.itsak.gr.

Koukis, G. et al, 2008. Engineering Geological - Geotechnical conditions and retention measures after the $8^{\text {th }}$ June 2008 earthquake in Santomeri Village, W. Greece. Technical Report, University of Patras, Department of Geology, 52 pp, Patra

Palmstrom, A., 1982. The volumetric joint count - a useful and simple measure of the degree of rock jointing", Proc. 4th congr. Int. Assn. Engng. Geol., Delhi 5, pp. 221 - 228.

RocScience Inc, 2003. RocFall Advanced Tutorial. Rocscience Inc, 8pp.

RocScience Inc, 2004. RocFall V.4, Rocscience Inc, Canada.

Tsiambaos, G. and Sabatakakis, N. (2000). "Considerations on RMR classification system concerning limestone slope stability", Proceedings of the International Conference on Geotechnical and Geological Engineering (GeoEng2000), Melbourne, pp.19 - 24.

Vagenas, N., 2009. Rockfall analyses of Rockfall events induced by the $8^{\text {th }}$ June 2008 earthquake in Santomeri Village, W. Greece. Master Thesis, University of Patras, Department of Geology, 304 pp, Patra 